\title{
THE POSITION OF THE FINANCIAL COMPONENT IN THE PARADIGM OF MODERN ECONOMIC DIPLOMACY
}

\author{
Kostyantyn Flissak', Darya Glukhova²
}

\begin{abstract}
At the beginning of the 21 st century, most subjects of international economic relations announced a course to liberalize the world economy both as a whole and as its individual components. At the same time, under the influence of geopolitical and geo-economic aspirations, state instruments of a protectionist nature were increasingly used. Global economic development has become a hostage to such processes. In such circumstances, the efficiency of individual business entities has begun to decline. Innovative tools were needed to prevent this. One of them was economic diplomacy, which has acquired a special role in providing the promotion of the interests of both national economies as a whole and their individual subjects. At the same time, economic diplomacy itself covers different areas of economic activity and not all of them are investigated to the same extent. The purpose of the article is to study and analyze the financial component of economic diplomacy in modern conditions, the specifics of its formation and development, aimed at improving the national system of promoting national interests both within the state and abroad. To achieve this goal, the research is focused on the following tasks: to consider and analyze the theoretical basis of the financial component of economic diplomacy, to highlight its manifestations in various forms of international economic relations, to determine the main imperatives of state support for international investment partnership. Special attention is paid to the issues of external borrowing and the movement of public debt funds from the point of view of the influence of economic diplomacy on them. Based on the results of this review, a whole number of theoretical conclusions were made, which at the same time establish the basis for further research of the considered problem. Methodology. In the process of preparing the article, methods of scientific abstraction, observation, analysis and synthesis, generalization, as well as statistical and economic methods were used to assess a number of financial and economic indicators of state development in order to identify the weaknesses and prospects for the impact of economic diplomacy tools on them. The information and analytical base for the study are materials and analytical reports of international organizations dealing with the issues under consideration (UNCTAD, IMF, World Bank), regulatory and statistical data of state authorities of Ukraine and the United States, the results of scientific research of modern scientists from different countries. The results of the study show that providing the proper efficiency of foreign economic activity requires the use of a set of tools to promote and support its subjects. Economic diplomacy plays a significant role in this sphere. The development level of international economic relations actualizes the justification of the modern paradigm of the financial component, mechanisms for applying the tools of economic diplomacy in financial issues. All this requires a clear delineation and structuring of object-by-object areas and directions of efforts. Only on this basis, an effective mechanism for implementing the financial component of economic diplomacy can be formed. The practical implications of the scientific research are to find out the current state of economic diplomacy mechanisms in the financial sphere, trends in their development, and potential consequences for other states (including Ukraine). Value/originality. The studied mechanisms and practice of using economic diplomacy in the sphere of the financial component, in particular in issues of interstate investment partnership, external government borrowing, and work with public debt deserve attention from the relevant state structures of Ukraine on the implementation of tools and standards of economic diplomacy in this area. In addition, this
\end{abstract}

\footnotetext{
Corresponding author:

${ }^{1}$ West Ukrainian National University, Ukraine.

E-mail: Flissak.K@ukr.net

ORCID: https://orcid.org/0000-0002-0980-2398

ResearcherID: P-9986-2018

${ }^{2}$ Taras Shevchenko University of Kyiv, Ukraine.

E-mail: gdarja03@gmail.com

ORCID: https://orcid.org/0000-0003-4734-4268
} 
Vol. 7 No. 3, 2021

study can serve as a basis for further research, since the considered problem contains the significant potential for further investigations in subsequent scientific publications.

Key words: national interests, economic diplomacy, foreign economic activity, global economic development, investment, state debt.

JEL Classification: F13, F21, F63, O24

\section{Introduction}

The world economic processes of the globalization era are accompanied, on the one hand, by the liberalization of market relations, the expansion of forms and methods of international economic cooperation, the unification of standards and regulatory requirements for the cross-border movement of goods, services, capital and labor, and on the other hand, by the strengthening of the struggle for markets of raw materials and resources, for markets of products, increased competition and the use of noncompetitive methods of promoting their own interests. Periodically occurring crisis phenomena and force majeure situations, including the 2020-2021 pandemic of COVID-19, are adding to the negative impact. In these circumstances, the importance of intensifying the efforts of states to defend their national interests increases. At the same time, it is difficult to overestimate the role and opportunities of economic diplomacy. In the context of the range of problems under consideration, the financial sphere is an important direction for the efforts of economic diplomacy in practice in the system of international economic relations. The theoretical and practical aspects of its various components (such as the financial interest of states in commodity expansion on the international market, international capital flows, investment flows, external borrowing, and regulation of external debt) have been and are the subject of research by different experts and scientists, in particular, such as N. Bayne (2011), P.A.G. van Bergeijk (2009), G. Dieckheuer (2001), M. Eng, F.A. Lees, and L.J. Mauer (1995), A. Filipenko and O. Rogach (2005), P. Krugman and M. Obstfeld (2018), O. Sharov (2008), R. Jackson and G. Sorensen (2013), W. Vergun and O. Stupnytzkiy (2009), H. Wagner (2009), S. Woolcock (2016) and others.

At the same time, the analysis of professional publications on the problems of international economic relations and foreign economic activity shows that the study of the financial component of economic diplomacy and the use of its tools in this area is practically ignored. The relevance of the problem also is in the fact that governments of states constantly face new challenges that require an adequate response in issues of diplomatic support in the financial segment of international relations. It should be noted that the possibilities of the sphere under consideration have significant potential in providing the effectiveness of the financial component of foreign economic relations, in preventing negative manifestations and crisis phenomena, and in resolving existing problems. Justification of the modern paradigm of the financial component, mechanisms for applying the tools of economic diplomacy in financial matters requires a clear delineation and structuring of object-by-object spheres and directions of efforts. Only on this basis, an effective mechanism for implementing the financial component of economic diplomacy can be formed.

\section{Financial component of economic diplomacy}

The practice of international relations, bilateral and multilateral economic partnership of countries constantly puts the need to coordinate financial parameters in trade and economic relations, investment cooperation, international cooperation, migration processes, and issues of innovation development on the agenda. Theoretical justifications of the practical implementation of the economic diplomacy's financial component require a clear structuring, first of all, of its objects, which include financial aspects: a) foreign trade (price and performance components); b) investment cooperation; c) international cooperation; d) external borrowing.

Price aspects of foreign trade comprise compliance with price parameters in the fulfillment of trade operations, optimization of export prices, prevention of dumping and anti-dumping actions from the side of partners, countering discriminatory manifestations against national subjects of economic activity in foreign markets. Providing compliance with price parameters and optimizing prices represent the basis on which the final financial result is formed both directly by the exporting entity and by the country from which the export is carried out. For the exporter, the financial result is profit, and for the country of origin of export - export duty and corresponding tax revenues to the budget. In addition, the financial component of economic diplomacy in foreign trade includes the prevention and protection against dumping, as so as anti-dumping measures from the side of partners can result in appropriate trade, economic and financial sanctions (export restrictions on relevant commodity items with all the consequences that follow from this, as well as direct penalties) (Yankiv, Flissak 2020). With the assistance of applying the tools of economic diplomacy, it becomes possible to significantly increase 
the efficiency of foreign trade operations due to the financial component. In foreign trade operations, the financial component of economic diplomacy should cover the activities of diplomatic missions in the host countries in issues of countering discriminatory manifestations from the side of foreign partners in relation to national subjects of foreign economic activity in markets abroad. This problem is particularly relevant for Ukraine.

Financial aspects of investment cooperation include the volume of attracting foreign investment in the national economy, investing funds by national investors in projects abroad, and ensuring that risks for investors are minimized. Since the second position in foreign economic activity after export-import operations is occupied by capital movement or, in other words, investment cooperation, so direct investment is of particular interest to the country's economy. However, the movement of investment capital always has two sides: from the point of view of the recipient country it is an investment of capital in its economy, and for the investor country it is the export of capital. At the same time, the export of capital for the investor country can be considered both positively and negatively. The investment is positive if the capital is used more efficiently outside the investor country in comparison to the investment of the same capital within the country itself. From the point of view of the investor country, investing capital abroad may be negative if there is a shortage of funds for domestic investment and the development of the national economy. From the point of view of national interests, such exports of capital are classified as harmful and posing threats to the country's economic and national security. This is one of the objects of economic diplomacy in promoting the national interests of the state.

The financial components of international financial cooperation, which we consider objects of economic diplomacy, are the financial support of cooperative networks, increasing their income and reducing costs, minimizing risks in achieving foreign economic goals, combining financial resources to implement significant financial projects (Kaufmann, 1990, Wirtschaftsförderung Sachsen $\mathrm{GmbH}, 2019)$. The financial component of international cooperation is primarily manifested at the stage of planning and determining the need for financial support, the forms of which can be: bank loans, warranties, financial intermediation, and financial participation of the cooperation center, as well as the insurance system for cooperation partners. The experience of foreign economic activity of a number of countries, primarily the Federal Republic of Germany, regarding their active position in diplomatic support of the financial component of international cooperation confirms that this is an intensive tool for national exporters to develop new markets abroad. During the creation and further development of a system of international cooperation relations and developing international cooperation using the tools of economic diplomacy, the financial component covers the issues of financial support for cooperative networks, increasing revenues and reducing costs, minimizing risks in achieving foreign economic goals. In the area of external borrowing, providing of which should account for a significant share of the financial component of economic diplomacy, we highlight actions to support the reception of funds in the formation of public debt, its repayment, servicing and possible restructuring.

\section{Imperatives of state support for international investment partnership}

A significant segment in the financial component of both foreign economic activity and its state support by the tools of economic diplomacy is occupied by investment activities. Since one of the challenges of the globalized world economic system in relation to national economies is the need to optimize their participation in the international division of labor, this increases the importance of the investment segment of foreign economic activity in achieving economic growth in a competitive environment with priority provision of national interests. When making decisions on new investments, it is necessary to balance investment flows into and from the country as much as possible. At the same time, it is extremely important to take into account the impact of investments on the economic growth of countries, on the volume of GDP, ensuring financial stability, solving problems with the employment of the population, and on the level of economic security of states. In the context of the country's participation in integration processes, the systematization of elements and components in forming the basis for investment expansion in foreign markets becomes particularly relevant. For Ukraine, this moment is of particular importance both for theory and practice due to the lack of such developments here. The state of investment cooperation of Ukraine is characterized by the data in Table 1 , and Table 2 shows data on the countries that are the main investors for the Ukrainian economy.

The dynamics of the share of accumulated direct investment in GDP (Table 1) indicates that the presence of national investors of Ukraine in foreign markets is insignificant. This is due to the lack of both necessary capital and a state system of assistance and support of national investors in expanding their activity outside the country. Also, the need for further improvement of the investment climate in terms of developing the legal and organizational framework to increase the capacity of mechanisms for ensuring a favorable investment climate and forming the basis for maintaining and improving the competitiveness of the 
Vol. 7 No. 3, 2021

Table 1

Dynamics of annual direct investment and its share in GDP of Ukraine

\begin{tabular}{|c|c|c|c|c|}
\hline & \multicolumn{2}{|c|}{ Annual direct investment in and out Ukraine, in $m$. USD } & \multicolumn{2}{|c|}{$\begin{array}{l}\text { Dynamics of the share of accumulated direct investment, } \\
\text { in \% of GDP of Ukraine }\end{array}$} \\
\hline & $\begin{array}{l}\text { from foreign countries } \\
\text { into Ukraine }\end{array}$ & from Ukraine abroad & $\begin{array}{l}\text { from foreign countries into } \\
\text { Ukraine }\end{array}$ & from Ukraine abroad \\
\hline 2009 & 4816 & 162 & 37.31 & 4.83 \\
\hline 2010 & 6495 & 736 & 38.87 & 4.81 \\
\hline 2011 & 7207 & 192 & 35.95 & 4.03 \\
\hline 2012 & 8401 & 1206 & 37.05 & 4.39 \\
\hline 2013 & 4499 & 420 & 36.57 & 4.27 \\
\hline 2014 & 410 & 111 & 37.33 & 5.68 \\
\hline 2015 & 2961 & -51 & 47.26 & 8.18 \\
\hline 2016 & 3284 & 16 & 45.07 & 8.00 \\
\hline 2017 & 2601 & 8 & 38.55 & 6.66 \\
\hline 2018 & 2355 & -5 & 33.89 & 5.68 \\
\hline 2019 & 3070 & 648 & 31.90 & 5.25 \\
\hline
\end{tabular}

Source: Compiled by the author based on data by UNCTAD Foreign direct investment: Inward and outward flows and stock (2021)

national economy remains relevant for Ukraine. It is the investment climate in the country that is a significant reason for the outflow of investment. Thus, in 2020, according to the National Bank of Ukraine, the total net outflow of foreign investment from Ukraine amounted to 870 million USD, and for the first quarter of 2021 300 million USD.

Here it is appropriate to draw attention to the practice of the EU countries in promoting national interests in the investment sphere and the real effectiveness of using the means of economic diplomacy, in particular, in Slovakia (Flissak, Drakokhrust, 2021) and Poland (Yankiv, Flissak, Kozłowski, 2020). In particular, Poland's current economic policy in the field of foreign investment is focused on creating opportunities for Polish companies investing abroad. Confirmation of the state's actions in this area is Resolution No. 3/2018 of the Council of Ministers of Poland dated January 3, 2018 on the "Program to support investments of importance for the Polish economy for 2011-2023". This program is one of the tools including economic diplomacy for support of investment projects, and is closely linked to strategic development documents; it contains clear goals to provide investment support, which are of particular importance for the development of innovation and competitiveness, as well as identify priority sectors in which investment will be supported.

Analysis of the practice by which the necessary dynamics of the investment segment of foreign economic activity in such EU countries as Poland, Slovakia, Hungary, and the Czech Republic is providing, as so as the effective attraction of FDI to the national economy and successful expansion of investment presence in foreign markets, increases the role and influence of state regulation of these processes in the presence of the market status. This activity is manifested in the appropriate legislative and regulatory support for investment cooperation, in the use of a wide range of financial and institutional support for investment activities, and in the creation of a network of structures for investment policy implementation.

\section{External borrowing in the sphere of economic diplomacy influence}

A separate and independent place in the systematic regulation and support of activities in the field of external borrowing should be occupied by a set of measures taken by the state including applying diplomatic tools. As it is known, in the market economy the appearance of debt can objectively be both a basis and a consequence of financial, economic, and commercial activities. That is why an integral element of the globalized world economic system in resolving the problem of insufficient funds for economic development, implementation of socio-economic development programs, financial support for the introduction of new and cutting edge technologies and innovations is the attraction of thirdparty funds and external financial resources. At the macro level usually are turned to both internal and external borrowings. As a result of such fund attractions, debts arise at the government level - as state and stateguaranteed debts.

Issues of external debt in international economic activity have become particularly relevant in recent decades, and the problem of improving the efficiency of external borrowing and resolving external debts has become particularly acute for the economic diplomacy of countries under the influence of the global financial and economic crisis of 2008-2010. To solve it, both at the level of states and international organizations, a whole system of mechanisms and instruments of influence is used (Dieckheuer, 2001), among which economic diplomacy plays a special role. Here it is necessary 
Table 2

Main investment partners of Ukraine in amounts of direct investments, at the end of the year, in percent of total amounts

\begin{tabular}{|c|c|c|c|c|c|c|}
\hline & 2010 & 2013 & 2014 & 2015 & 2018 & 2019 \\
\hline $\begin{array}{l}\text { World, } \\
m \ln U S D\end{array}$ & 47956 & 58864 & 29227 & 43780 & 44009 & 51387 \\
\hline 1. & $\begin{array}{c}\text { The Netherlands } \\
26.3\end{array}$ & $\begin{array}{l}\text { Cyprus } \\
32.2\end{array}$ & $\begin{array}{l}\text { Cyprus } \\
21.2\end{array}$ & $\begin{array}{l}\text { Cyprus } \\
34.4\end{array}$ & $\begin{array}{l}\text { Cyprus } \\
30.2\end{array}$ & $\begin{array}{l}\text { Cyprus } \\
31.2\end{array}$ \\
\hline 2. & $\begin{array}{c}\text { Cyprus } \\
23.3\end{array}$ & $\begin{array}{c}\text { The Netherlands } \\
17.9\end{array}$ & $\begin{array}{c}\text { The Netherlands } \\
19.2\end{array}$ & $\begin{array}{c}\text { The Netherlands } \\
19.3\end{array}$ & $\begin{array}{l}\text { The Netherlands } \\
21.9\end{array}$ & $\begin{array}{l}\text { The Netherlands } \\
22.8\end{array}$ \\
\hline 3. & $\begin{array}{c}\text { Germany } \\
11.2\end{array}$ & $\begin{array}{c}\text { Russia } \\
7.0\end{array}$ & $\begin{array}{c}\text { Germany } \\
8.5\end{array}$ & $\begin{array}{c}\text { Germany } \\
4.9\end{array}$ & $\begin{array}{l}\text { Germany } \\
5.2\end{array}$ & $\begin{array}{c}\text { Switzerland } \\
6.2\end{array}$ \\
\hline 4. & $\begin{array}{c}\text { Russia } \\
6.2\end{array}$ & $\begin{array}{c}\text { Germany } \\
6.3 \\
\end{array}$ & $\begin{array}{c}\text { United Kingdom } \\
6.9 \\
\end{array}$ & $\begin{array}{l}\text { United Kingdom } \\
4.2\end{array}$ & $\begin{array}{c}\text { Switzerland } \\
4.7 \\
\end{array}$ & $\begin{array}{c}\text { Germany } \\
4.9 \\
\end{array}$ \\
\hline 5. & $\begin{array}{c}\text { United Kingdom } \\
4.4\end{array}$ & $\begin{array}{c}\text { Austria } \\
4.7\end{array}$ & $\begin{array}{c}\text { Russia } \\
6.2\end{array}$ & $\begin{array}{c}\text { British Virgin Islands } \\
3.7\end{array}$ & $\begin{array}{c}\text { United Kingdom } \\
4.3\end{array}$ & $\begin{array}{c}\text { United Kingdom } \\
4.2\end{array}$ \\
\hline 6. & $\begin{array}{c}\text { France } \\
3.8\end{array}$ & $\begin{array}{c}\text { Switzerland } \\
4.6\end{array}$ & $\begin{array}{c}\text { Switzerland } \\
5.3\end{array}$ & $\begin{array}{c}\text { France } \\
3.5\end{array}$ & $\begin{array}{c}\text { Russia } \\
2.8\end{array}$ & $\begin{array}{c}\text { Austria } \\
2.9\end{array}$ \\
\hline 7. & $\begin{array}{c}\text { Austria } \\
3.5 \\
\end{array}$ & $\begin{array}{c}\text { United Kingdom } \\
4.1 \\
\end{array}$ & $\begin{array}{c}\text { France } \\
5.2 \\
\end{array}$ & $\begin{array}{c}\text { Austria } \\
3.1 \\
\end{array}$ & $\begin{array}{c}\text { Austria } \\
2.6 \\
\end{array}$ & $\begin{array}{c}\text { Russia } \\
2.2 \\
\end{array}$ \\
\hline 8. & $\begin{array}{c}\text { United States } \\
2.6 \\
\end{array}$ & $\begin{array}{c}\text { France } \\
3.1 \\
\end{array}$ & $\begin{array}{c}\text { Austria } \\
4.3 \\
\end{array}$ & $\begin{array}{c}\text { Russia } \\
3.0 \\
\end{array}$ & $\begin{array}{c}\text { British Virgin Islands } \\
2.4 \\
\end{array}$ & $\begin{array}{c}\text { France } \\
2.2 \\
\end{array}$ \\
\hline 9. & $\begin{array}{c}\text { Switzerland } \\
2.6 \\
\end{array}$ & $\begin{array}{c}\text { United States } \\
2.2 \\
\end{array}$ & $\begin{array}{c}\text { United States } \\
3.4 \\
\end{array}$ & $\begin{array}{c}\text { Switzerland } \\
2.1 \\
\end{array}$ & $\begin{array}{c}\text { France } \\
1.8 \\
\end{array}$ & $\begin{array}{c}\text { Poland } \\
1.7 \\
\end{array}$ \\
\hline 10. & $\begin{array}{c}\text { Poland } \\
1.9 \\
\end{array}$ & $\begin{array}{c}\text { British Virgin Islands } \\
2.0 \\
\end{array}$ & $\begin{array}{c}\text { Poland } \\
2.9 \\
\end{array}$ & $\begin{array}{c}\text { United States } \\
2.0 \\
\end{array}$ & $\begin{array}{c}\text { Poland } \\
1.8 \\
\end{array}$ & $\begin{array}{c}\text { Luxembourg } \\
1.6 \\
\end{array}$ \\
\hline
\end{tabular}

Source: Compiled by the author based on data by IMF (2020)

to emphasize that one of the defining directions of ensuring effective foreign economic activity of own country is the orientation of economic diplomacy to the main vectors of economic and political priorities, as well as the mandatory coordination of its goals with the strategic guidelines of the state's foreign economic policy. Economic diplomacy means should support the country's external debt from the stage of the search of partners and making agreements with creditors up to the stage of its repayment. Often, as practice shows, diplomats need to make significant efforts to resolve emerging problems, eliminate bottlenecks and contradictions between the parties (creditors and borrowers) in the process of using external borrowing.

The analysis of international practice shows that the problems of public debt and external borrowing are among the most relevant in the modern economic life of each country, regional supranational entities, and international organizations. In a number of countries, the level of public debt exceeds or is quite high relative to GDP, which is confirmed by the data in Table 3.

Certain distortions in the use of financial and credit resources, ignoring the requirements for effective investment of credit resources, excessive enthusiasm for consumer crediting and unsecured provision of loans in a number of European countries (primarily in Greece, Portugal, Spain, Iceland, Italy) and in the United States have greatly aggravated the problem of external debt. To a certain extent, these problems also affected Ukraine, where coincided the impact of the global financial crisis and the accumulation of internal unresolved problems in part of accumulating the necessary financial resources for the needs of economic development, ensuring employment, and preventing a fall in social standards. The problem of external debt in Ukraine is also aggravated by the lack of own funds for the modernization of production sectors, the high level of deterioration of fixed production assets, the high level of the shadow sector in the economy, and the lack of funds for timely financing of social programs and activities.

Since in the modern world external debt has become a common phenomenon in the world economy, it should be mentioned that in the system of the world economy there are two poles of external debt: on the one hand, a small group of creditor countries and international credit organizations; on the other hand, a large group of debtor countries. At the same time, the dominant position for a long time was that developing countries and economies in transition are more exposed to external borrowing. But the trends of the 21 st century clearly deny this: the most developed economies in the world are among the main debtors. According to the International Monetary Fund, the highest level of external debt-to-GDP ratio is found in economically developed countries. By absolute volumes of public debt, the first position is consistently occupied by the United States, the dynamics of which over the past decade are characterized by the data in Table 4 . 
Vol. 7 No. 3, 2021

Table 3

Rating of countries by the amount of public debt relative to GDP, in percent

\begin{tabular}{|c|c|c|c|c|c|c|}
\hline & \multicolumn{2}{|c|}{2013} & \multicolumn{2}{|c|}{2015} & \multicolumn{2}{|c|}{2017} \\
\hline & State & $\begin{array}{c}\text { State debt i } \\
\text { n per cent of GDP }\end{array}$ & State & $\begin{array}{c}\text { State debt } \\
\text { in per cent of GDP }\end{array}$ & State & $\begin{array}{c}\text { State debt } \\
\text { in per cent of GDP }\end{array}$ \\
\hline 1. & Japan & 226.1 & Japan & 227.9 & Japan & 236.4 \\
\hline 2. & Zimbabwe & 202.4 & Zimbabwe & 205.3 & Greece & 181.9 \\
\hline 3. & Greece & 175.0 & Greece & 182.0 & Lebanon & 152.8 \\
\hline 4. & Italy & 133.0 & Lebanon & 138.8 & Yemen & 135.5 \\
\hline 5. & Iceland & 130.5 & Italy & 135.8 & Barbados & 132.9 \\
\hline 6. & Portugal & 127.8 & Portugal & 129.0 & Italy & 131.5 \\
\hline 7. & Ireland & 124.2 & Eritrea & 122.6 & Eritrea & 131.2 \\
\hline 8. & Jamaica & 123.6 & Jamaica & 122.5 & Cape Verde & 126.0 \\
\hline 9. & Lebanon & 120.0 & Cape Verde & 116.2 & Sudan & 126.0 \\
\hline 10. & Cyprus & 113.1 & Grenada & 110.0 & Portugal & 125.6 \\
\hline 11. & Sudan & 111.0 & Cyprus & 107.0 & Gambia & 123.2 \\
\hline 12. & Grenada & 110.0 & Belgium & 107.0 & Congo & 119.1 \\
\hline 13. & Singapore & 105.5 & Singapore & 105.6 & Singapore & 110.9 \\
\hline 14. & Eritrea & 104.7 & Puerto Rico & 105.4 & Jamaica & 104.1 \\
\hline 15. & Belgium & 102.4 & Ireland & 101.2 & Egypt & 103.3 \\
\hline 16. & Puerto Rico & 96.5 & Barbados & 101.0 & Belgium & 103.2 \\
\hline 17. & Spain & 93.7 & Spain & 101.0 & Bhutan & 102.4 \\
\hline 18. & France & 93.4 & Bhutan & 98.5 & Mozambique & 102.2 \\
\hline 19. & Egypt & 92.2 & France & 98.2 & Cyprus & 99.3 \\
\hline 20. & United Kingdom & 91.1 & Canada & 95.4 & Belize & 99.0 \\
\hline 21. & Barbados & 90.5 & Ukraine & 94.9 & Spain & 98.4 \\
\hline
\end{tabular}

Source: Compiled by the author based on data by Central Intelligence Agency (2021)

Table 4

Dynamics of the US state debt

\begin{tabular}{|c|c|c|c|c|c|}
\hline \multirow{2}{*}{} & \multirow{2}{*}{$\begin{array}{c}\text { GDP, } \\
\text { in bln USD }\end{array}$} & \multicolumn{4}{|c|}{ Total Public Debt Outstanding, at the end of the year } \\
\cline { 3 - 6 } & & Amount, & \multirow{2}{*}{ in percent to GDP } & \multicolumn{2}{c|}{ Growth compared to the previous year } \\
\cline { 3 - 6 } & 14992 & 14025.2 & 93.5 & bln USD & в \\
\hline 2010 & 15543 & 15222.9 & 97.9 & 1197.7 & 108.5 \\
\hline 2011 & 16197 & 16432.7 & 101.5 & 1209.8 & 107.9 \\
\hline 2012 & 16785 & 17351.9 & 103.4 & 919.2 & 105.6 \\
\hline 2013 & 17527 & 18141.4 & 103.5 & 789.5 & 104.5 \\
\hline 2014 & 18225 & 18922.2 & 103.8 & 780.8 & 104.3 \\
\hline 2015 & 18715 & 19976.8 & 106.7 & 515.9 & 105.6 \\
\hline 2016 & 19519 & 20492.7 & 105.0 & 1481.4 & 102.6 \\
\hline 2017 & 20580 & 21974.1 & 106.8 & 1227.3 & 107.2 \\
\hline 2018 & 21433 & 23201.4 & 108.3 & 4546.4 & 105.6 \\
\hline 2019 & 20933 & 27747.8 & 132.6 & 119.6 \\
\hline 2020 & & & & \\
\hline
\end{tabular}

Source: Compiled by the author based on data by the US Treasury (2021), the WorldBank (2021), the International Monetary Fund, the World Economic Outlook Database (2021)

A retrospective assessment of the amount and dynamics of the US state debt over the past decade is especially indicative. In 1980, the US state debt was $32.5 \%$ of GDP, in $1990-54.2 \%$, in $2000-55.5 \%$, and since 2012 - exceeded 100\% (Table 4) (UNCTAD Handbook of Statistics, 2003, UNCTAD Handbook of Statistics, 2009). The given data indicate that it is impossible to maintain the national economy and budget without increasing public debt and external borrowing. In fact, one of the main roles in the increase of American GDP over the past decades belongs precisely due to the growth of state debt. On this basis, a block of target tasks for American economic diplomacy is formed with the appropriate definition of areas of activity, spheres, and regions of influence using the necessary methods and forms. It is mandatory to take into account the level of the financial component of foreign economic activity in the country's economic development strategy. This applies to export-import operations, investment partnerships, international 
cooperation, and participation in international financial institutions.

Analytical assessment of the situation involving external borrowing, the state of use and servicing of Ukraine's external debt serves as the basis for determining the "problematic" points of application of efforts of economic diplomacy representatives both within the country and in the host states of diplomatic missions - both current and potential creditors. An important element here should be considered the formation of a system of evaluation criteria both on the part of foreign lenders in relation to Ukraine (regarding the reputation of the borrower, the level of risks for repayment of funds, terms and volumes of loans), and on the Ukrainian side in relation to desired and expected borrowings (regarding terms, special notes, price, possible benefits, procedures for servicing, repayment, possible restructuring, etc.). The dynamics of Ukraine's gross external debt over the past decade are reflected in Table 5.

The analysis of the considered problem shows that the larger the amount of external debt is, the more often problem situations and conflicts of interest between creditors and borrowers arise. In addition, under favorable circumstances for creditors and significant debt obligations of borrowers, creditor countries and international creditor organizations gain opportunities for strong economic and political influence in different parts of the world in their strategic interests. This once again confirms the need for active diplomatic support and the use of economic diplomacy tools in resolving external debt problems.

At the same time, to a large extent, the issue of activating the use of means and methods of economic diplomacy in solving a wide range of emerging problems, in preventing obviously unprofitable steps on the part of borrowers-subjects of external debt, especially in parts of the state and state-guaranteed debt in the context of defending and protecting the national economic interests of the state remains actual. This is especially important for the economic diplomacy of Ukraine. At the same time, it is important to take into account that the use of funds that form the country's public debt implies its permissible limits, exceeding which signals an inefficient, illiquid, and non-payment economy.

Thus, the efforts of economic diplomacy in matters of external borrowing should be distributed in two main areas: firstly, to intensify cooperation with international financial organizations and international regional development banks in order to attract the necessary external financial and credit resources to the national economy; secondly, to repay and restructure external debt and external borrowing, in other words, to implement effective debt diplomacy.

Comprehensive coverage of all segments of the financial component of economic diplomacy is the key to preventing risks and undesirable problem situations for the state, as well as providing the provision of national interests, including Ukraine, in foreign trade, international investment partnership, and international cooperation, in the implementation of state economic and social development programs.

\section{Conclusions}

Providing the proper efficiency of foreign economic activity requires the use of a set of tools for the promotion of interests and necessary support of its subjects. In this sector, economic diplomacy plays a significant role. The level of development of international economic relations actualizes the justification of the modern paradigm of the financial component, mechanisms for applying the tools of economic diplomacy in financial issues. All this requires a clear delineation and structuring of object-

Table 5

Dynamics of gross external debt of Ukraine (according to the IMF methodology)

\begin{tabular}{|c|c|c|c|c|c|}
\hline \multirow{2}{*}{} & \multirow{2}{*}{$\begin{array}{c}\text { GDP } \\
m n . \text { USD }\end{array}$} & $\begin{array}{c}\text { Gmount, } \\
\text { mn. USD }\end{array}$ & in percent to GDP & \multicolumn{2}{|c|}{ growth in comparison to the previous year } \\
\cline { 3 - 6 } & & 117346 & 86.3 & $\ldots$ & $\ldots$ \\
\hline 2010 & 135938 & 126236 & 77.4 & +8890 & $\ldots$ \\
\hline 2011 & 163110 & 134625 & 76.6 & +8389 & 107.6 \\
\hline 2012 & 175803 & 142079 & 77.5 & +7454 & 106.6 \\
\hline 2013 & 183379 & 126297 & 94.6 & -15782 & 88.9 \\
\hline 2014 & 133503 & 117668 & 129.3 & -8629 & 93.2 \\
\hline 2015 & 91009 & 112624 & 120.6 & -5044 & 95.7 \\
\hline 2016 & 93361 & 115451 & 102.9 & +2827 & 102.5 \\
\hline 2017 & 112176 & 114710 & 87.6 & -741 & 99.4 \\
\hline 2018 & 130904 & 121739 & 79.1 & +7029 & 106.1 \\
\hline 2019 & 153903 & 125690 & 80.8 & +3951 & 103.2 \\
\hline 2020 & 155568 & &
\end{tabular}

Source: Compiled by the author based on data by the National Bank of Ukraine (2021), State Statistics Service of Ukraine (2021) 
by-object areas and directions of efforts. Only on this basis, an effective mechanism for implementing the financial component of economic diplomacy can be formed. The study of this problem allowed us to make the following conclusions:

1. Theoretical reasoning for the practical implementation of the financial component of economic diplomacy give grounds to clearly structure its objects, which include financial aspects: foreign trade (price and performance components); investment cooperation; international financial cooperation; external borrowing, and external debt.

2. In foreign trade operations, the financial component of economic diplomacy, in addition to observing price parameters in the implementation of trade operations, optimizing export prices, should cover the activities of diplomatic missions in the host countries in countering discriminatory manifestations from side of foreign partners in relation to national subjects of foreign economic activity in markets abroad. This problem is particularly relevant for Ukraine.

3. The financial components of international financial cooperation, as objects of economic diplomacy, should include financial support for cooperative networks, increasing their income and reducing costs, minimizing risks in achieving foreign economic goals, combining financial resources to implement significant financial projects. These aspects can and should play a significant role in the implementation of integration efforts and programs of the countries concerned.

4. Due to the fact that in the financial component of both foreign economic activity and its state support by economic diplomacy tools a significant segment here is occupied by investment activities, and become necessary appropriate actions on the part of national states. The experience of a number of EU countries shows that in matters of effective attraction of FDI to the national economy and successful expansion of investment presence in foreign markets, state regulation of these processes in the market economy plays a significant role. This is reflected in the legislative and regulatory support of investment cooperation, the use of a wide range of financial and institutional support for investment activities, the creation of a network of structures, both within countries and abroad, for the implementation of investment policy.

5. In matters of external borrowing and external debt, according to the conducted research, it is advisable to distribute economic efforts in two main areas: firstly, to intensify cooperation with international financial organizations and international regional development banks in order to attract the necessary external financial and credit resources to the national economy; secondly, to repay and restructure external debt and external borrowing, that is, to implement effective debt diplomacy.

\section{References:}

Bayne, N., \& Woolcock, S. (2011). The New Economic Diplomacy. London: Ashgate Publishing Limited.

van Bergeijk Peter A. G. (2009). Economic Diplomacy and the Geography of International Trade. Cheltenham, Northampton: Edward Elgar.

Central Intelligence Agency (2021). Rating of countries by public debt. Available at: https://nonews.co/directory/ lists/countries/debt

Dieckheuer, G. (2001). Internationale Wirtschaftsbeziehungen - München; Wien; Oldenburg.

Eng, M. V., Lees, F. A., \& Mauer, L. J. (1995). Global Finance. HarperCollins Colege Publishers.

Flissak, K., \& Drakokhrust, T. (2021). Modern paradigm of national interests promoting in foreign economic activity of Slovakia. Baltic Journal of Economic Studies, 7(2), 224-232. DOI: https://doi.org/10.30525/22560742/2021-7-2-224-232

IMF (2020). Inward/Outward Direct Investment Positions (Top 20 Counterpart Economies), Reporting Economy: Ukraine. Available at: https://data.imf.org

International Monetary Fund. World Economic Outlook Database (2021). Available at: https://www.imf.org/en/ Publications/WEO/weo-database/2021/April/weo-report

Jackson R., \& Sorensen, G. (2013). Introduction to International Relations: Theories and Approaches (the fifth edition). Oxford.

Kaufmann, F. (1990). EG-Binnenmarkt: Die Grenzüberschreitende Kooperation mittelständischer Unternehmen; empirische Analise von Möglichkeiten, Vorraussetzungen und Erfahrungen. Stuttgart: Poeschel.

Krugman, P., \& Obstfeld, M. (2018). International economics. Theory and policy, 11th edition. Pearson.

National Bank of Ukraine (2021). Gross external debt of Ukraine (according to the IMF methodology). Available at: https://bank.gov.ua/ua/statistic/sector-external/data-sector-external\#4

Rogach O. (2005). International investment: theory and practice of business of multinational corporations. Kyiv: Lybid.

State Statistics Service of Ukraine (2021). Gross Domestic Product. Available at: www.ukrstat.gov.ua

Sharov, O. M. (2008). Ukraine: choosing a public debt management strategy. World of finance, 1(14), 7-9.

UNCTAD Foreign direct investment: Inward and outward flows and stock (2021). Available at: https://unctadstat.unctad.org/wds/TableViewer/tableView.aspx 
UNCTAD Handbook of Statistics (2003). United Nations, New York. UNCTAD Handbook of Statistics (2009). United Nations, New York. US Treasury (2021). Monthly Statement of the Public Debt of the United States. Available at: www.TreasuryDirect.gov Verhun, V. A. (2009). Joint investment institutions in the context of globalization of global financial markets. Kyiv: Kyiv University.

Wagner, H. (2009). Einführung in die Weltwirschaftspolitik. Oldenbourg Verlag München.

Wirtschaftsförderung Sachsen GmbH (2019). Absatzförderung / Kooperationen. Available at: www.wfs.sachsen.de Woolcock, S. (2016). European Union Economic Diplomacy. The Role of the EU in External Economic Relations. L.: Routledge. DOI: https://doi.org/10.4324/9781315581033

WorldBank (2021). GDP - United States. Available at: https://data.worldbank.org/indicator/NY.GDP.MKTP. $\mathrm{CD}$ ?locations $=\mathrm{US}$

Yankiv, M., \& Flissak, K. (2020). Sankcje gospodarcze we współczesnych relacjach międzynarodowych: nowe formy wdrażania. Kwartalnik nauk o przedsiębiorstwie, 57(4), 5-14. DOI: https://doi.org/10.33119/KNoP.2020.57.4.2

Yankiv, M., Flissak, K., \& Kozłowski, A. R. (2020). Dyplomacja w zagranicznej wspótpracy gospodarczej [Diplomacy in foreign economic cooperation]. Warszawa, CeDeWu. 